\title{
Improving Nursing Student's Speaking Ability Through Information Gap, Oral Report Activities at STIKES Merchubakti Jaya
}

\author{
Firdaus $^{1}$ and Sitti Fatimah ${ }^{2}$
}

\author{
${ }^{1}$ STIKes Mercubakijaya Padang, English Lecturer, Padang, Indonesia, firdausdahniur@gmail.com \\ ${ }^{2}$ Universitas Negeri Padang, English Lecturer, Padang, Indonesia, sitti.fatimahbing@gmail.com
}

\begin{abstract}
This research was aimed to improve the student's speaking ability through information gap and oral report activities in STIKes Merchubaktijaya Padang in comprehension, pronunciation, grammatical, vocabulary, and fluency aspects. The research used class action research. The subject of the research was 56 students of the second year of the nursing department in A class. Based on the data analysis, there was a significance improvement of the student's speaking ability in each cycle in accordance to the speaking rubric. The average of student's speaking ability in Cycle I was 2.80. There was 0.8 increasing comparing to pre-test score. In cycle II, the average score was increasing into 4.47. The result of the research indicated that the combination of the information gap and oral report activities in teaching speaking can improve the student's speaking ability in STIKes Merchubaktijaya Padang. The most significance was comprehension and fluency.
\end{abstract}

Keywords: Information gap activities, oral report activities, speaking ability.

\section{INTRODUCTION}

The process of communication to learn English language is important and it can't be carried on without having speaking skills. It is an interactive process for constructing and receiving information. This skill is important in language learning for communicating with couples or other English language speakers and that's why this skill is needed to carry out the conversation. Through speaking, we can learn other aspects of language such grammar, vocabulary, pronunciation, fluency, comprehension and others. Therefore, we are encouraged to use English language in daily communication.

Basically, one of the parts of teaching English is teaching speaking. The learners at school or at university level are successfully taught if the teacher can make the students motivate to speak. English teachers and lecturers are pushed to create a meaningful environment where meaningful communication takes place. Therefore, in order to develop communication skills which relate to their life and apply into the English classes, they can use many speaking activities. It hopes that these activities make the students more active and interested in the class and create the learning more enjoyable as well.

One of the higher university levels is nursing university. English speaking is also needed for nursing students because it will be very beneficial for them to develop their knowledge about English and also as a path way for them to get a job. The English lecturers may select the models for their English speaking class. To get better communication skills, the Directorate General of Higher
Education (Sub Direktorat KPS, 2008) states there are some models that can be modified in the teaching learning process in Student Centre Learning: small discussion, simulation, case study, discovery learning, role play, gap activities and etc. The main purposes of these activities are practicing the students to be able to interpret the content of oral text and in an interesting activity they can respond interactively.

When teaching speaking in the classroom, there are some obstacles which were related to speaking class that researcher's facing. The researcher has found some problems in teaching speaking in the classroom. Firstly, in language teaching class, while they are practicing, they seldom answer the question given by the peer correctly. Secondly, there are pauses so often while talking. Third, it is hard for them to get the right words in the right sentence or expression. Fourth, for vocabulary mastery, when the lecturer asks the meaning of the words but they often miss the meaning. Fifth, in grammatical items, they sometimes make mistake in expressing the words because of the grammatical error. The last is in the classroom atmosphere, the students are not really enthusiastic and interested in joining learning activities during the teaching learning process. Only a few students have great willingness to speak up voluntarily. The situations are difficult to be considered since for final test they do not have speaking test but written test. In fact, in their daily activities in the class the teacher sometimes gives scoring their speaking as daily mark and even for determining whether they have right to pass the subject. Thus, related to above situation, 
the researcher tries to select the suitable and interesting activities as an alternative way.

There are many ways that can be proposed to deal with the phenomena above that is by applying the right techniques that can improve students speaking ability. It can be done through information gap and oral report activities sequentially. An info gap activity is simply an activity where Person A knows something that Person B doesn't know and vice-versa. There is a gap in information between the two students. They both have information that the other need. Montoya (2011) states the Information gap activities refer to the fact that in real communication people normally communicate in order to get information they do not possess. The students are pushed to speak in order to give the information to their partner and to complete their own. Asrobi, Seken, \& Suarnajaya (2013) also states that Information gap activities is effective to encourage cooperative relationship. In short, the learners are activated to talk a lot and participated in the activities.

The students are required to tell about the information in front of the class. The oral report is the activity which is what they find as the most interesting news or reporting. According to Rahmawati (2017) states that there are some ways that can be applied in the classroom in order to keep the students actively participate that is free speaking through oral report. Marzuki (2017) also states that oral report technique is kind of oral presentation a proper solution because the time provided sufficiently for students to practice their speaking skill and the material discussed in the class is based on students' interest. It means that the students are given time to tell information in front of the class. Girard, Pinar and Trapp (2011) state that by exploiting oral report presentations in the classroom will develop students' interest to learn English and give a chance for students to communicate each other. That's why the students should share their information to others. As Brooks and Wilson (2014) also say that the students' language skills in sharing ideas may be developed if the teachers use poster presentation in the classroom.

Briefly, it can be concluded that information gap and oral report activities are a set well-design activities which is be able to stimulate the students to speak in front of the class. These activities need the students to speak actively in order to share their information. Then, their comprehension, fluency and confidence will come up automatically.

The research question in this research is how does information gap activities and oral report improve the students' speaking ability of the second year of Nursing Department in STIKES Merchubakti Jaya Padang academic year 2018/2019?

\section{METHOD}

This research was a classroom action research. Sagor (2000) states a classroom action research was done to help the teacher as the actor in the class to improve and refine his/her action. Tampubolon (2000) also mentions that classroom action research is done by the teacher in order to help them to get the solution of the certain issues in their classroom. Therefore, the aims of the research are to expose their problems, to enhance their speaking skill and to get the ways out of the problem appeared by implementing information gap and oral report activities. 56 students from second year of nursing department were taken as participants.

Considering the explanation above, to do the classroom action research, the researcher used collaborator where the researcher worked together with one of the English teacher in this institution. The teacher worked as an observer who observed the teaching learning process, and the researcher was the one who taught the students and implemented both activities to them. The instrument of the research was the test from the student. The teacher and researcher tried to collect the data and analyze it. The researcher implemented two cycles which was each cycles for 5 meetings. It was done by four phases of classroom action research; planning, acting, observing, and reflecting.

To see the improvement of the teaching activities of both activities, the researcher made two post tests. The researcher wanted to see their improvement in speaking aspects such comprehension, pronunciation, grammar, fluency, and vocabulary. Post test I was done after implementing the cycle I for 4 meetings, and post test II was done after implementing the cycle two for four meetings. The researcher gave assessment test based on the speaking rubric. After the result of the test was received, the researcher compared the result of the test pretest and post test of each cycles and calculated the students' mean score. Then, the researcher calculated the class result by percentage.

\section{RESULTS AND DISCUSSION}

\section{The Result from Observational Note}

Many things could be revised and discussed when the information gap and oral report activities were implemented. The observation check list would describe the strengths and weaknesses of the activities. Both teacher and researcher worked cooperatively to find out the best thing to do dealing to the teaching learning process. All should be discussed to avoid the missing thing in doing the activity, so it could be a material evaluation for the next action. In fact, there were still some parts of teaching process missing or over acted, however those shortcomings could be handled at the end. For example, the observation checklist from teacher would comment about the time management. There were too long in some parts and too short in another part. As a result, the materials were not implemented fully. Another one was about class controlling. Since the class was too big and the amount of students was about 56, some students couldn't follow the activity well. The teacher was supposed to put the students in the right position especially when they were divided into pair. Those comments were revised by teacher and wouldn't come in the next phase. The observation checklist also gave checklist to the material especially dealing with the vocabulary. The teacher had better to do 
limitation to the amount of vocabularies given. At the beginning of the activity, the students were still reluctant to follow the activities. They felt confused and would prefer to speak slow voice rather than to speak loudly with their peers. Sometimes they spoke with too many pauses and it made them difficult to express their ideas. It was caused by they didn't prepared well and didn't do practicing before they spoke. Those problems were revised and analyzed comprehensively in order to find the solution and became a smooth action for the next action. Finally, the activities could be implemented well and researcher felt very excited since the information gap and oral report activities could give a solution in overcoming the student's difficulties to speak English.

\section{A. The Result from the Test}

In analyzing the data, the researcher uses some steps in order to find or compare the student's test result from posttest I and posttest 2. First, calculating the student's mean score test by $\bar{x}=\frac{\Sigma x t}{n}$, then knowing the percentage of the students' score passing rank (KKM) by $P-\stackrel{F}{\sim} \times 100 \%$, and seeing the improvement score from test 1 and test 2 by $P=\frac{y_{1}-y}{y} \times 100 \%$

Based on the result of the speaking test from two activities (information gap and oral report), there was a tendency of improvement of the student's speaking ability for each cycle.

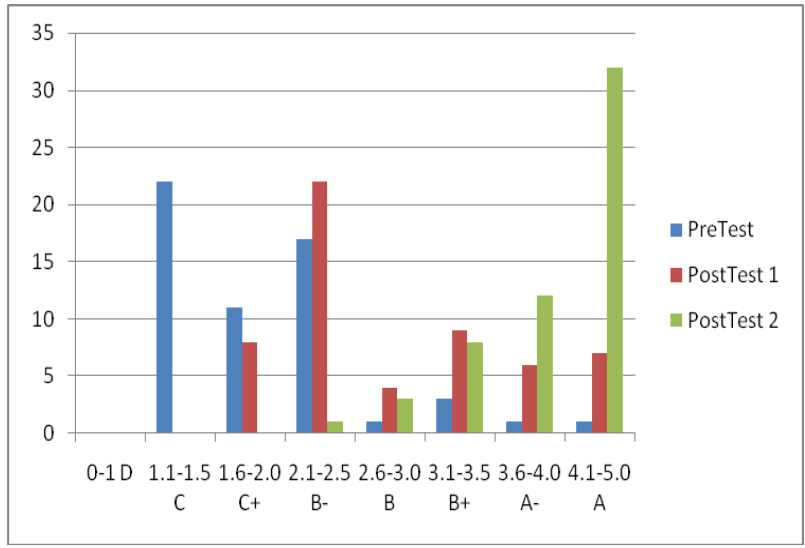

Figure 1. The result of the students' speaking score

Table 1: The Improvement of student's score from pretest to posttest 1 and posttest 2

\begin{tabular}{|l|c|c|c|}
\hline Test & Y & Y1 & Y2 \\
\hline Total test score & 1106 & 1566 & 2333 \\
\hline The mean class & 1.975 & 2.807 & 4.47 \\
\hline $\begin{array}{l}\text { Student } \\
\text { percentage } \\
\text { passing score }\end{array}$ & $85 \%$ & $100 \%$ \\
\hline
\end{tabular}

$Y=$ pre test, $Y 1=$ post test $1, Y 2=$ post test 2
The following figure is the improvement of each test

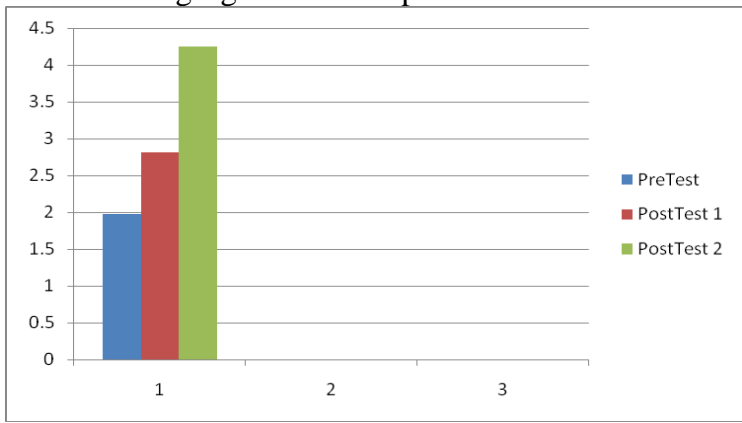

Figure 2. The improvement of each test

The following figure is the mean score based on the speaking aspects

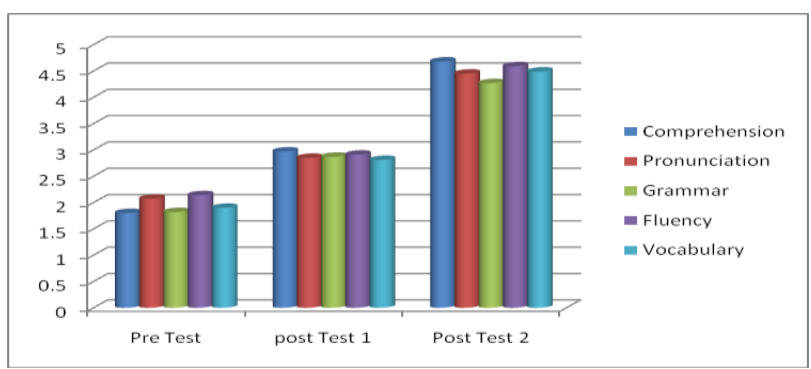

Figure 3. The mean score based on the speaking aspects

In the pretest, the student's mean score from both speaking activities was 1.97 . There was only $41 \%$ of the class percentage which could pass the minimum pass rank. It means that 33 students were failed. It also could be said that there were only 23 student pass the test minimum of 2.1.There was an increasing of student's mean score test in post test I in cycle 1 . The point became 2.80 . It means that $85 \%$ of the students could pass the test and only 8 students were failed from the minimum pass rank. The improvement was increasing in post test 2 in cycle 2 . The students who could pass the minimum pass rank were about 56. It means that all of the students were passed the test and got A or B in the test. From the aspect of speaking score test; comprehension, pronunciation, grammar, fluency, and vocabulary, there was significances on comprehension and fluency aspect from posttest 1 , and posttest 2 comparing with pretest. It means that both information gap and oral report activities could improve the student's speaking ability.

\section{CONCLUSION}

The study showed the student's speaking ability was increased and improved after implementing both information gap and oral report activities in the classroom. It was happened because of the student's participation in the activities and they enjoyed the activities since they were involved to share information each other. The use of the oral report activities after implementing information gap activities improved the student's comprehension and fluency comparing to grammar, pronunciation and vocabulary. It was happened because they reported the 
information that they had got from information gap activities.Therefore, information gap and oral report activities should be applied in teaching speaking as the way to improve their speaking ability. The researcher wished that this study could be carried on and preserved into the other aspect skills.

\section{ACKNOWLEDGMENTS}

The researcher really appreciates and feels thankful to the Director of STIKes Merchubaktijaya Padang who had given me a chance, to the teachers, and all students of Nursing Department for their support and cordial hand in completing this research. The researcher also wants to thank to the supervisor in English Education Study at Universitas Negeri Padang at Post Graduate Program who has guided and given her suggestions.

\section{REFERENCES}

[1] Asrobi, M., Seken, K. \& Suarnajaya, W. 2013. The Effect of Information Gap Technique and Achievement Motivation toward Students' Speaking Ability (An Experimental Study of the Tenth Grade Students of MAN SELONG). $e$ Journal Program Pascasarjana Universitas Pendidikan Ganesha Program Studi Pendidikan Bahasa Inggris, Volume 1 Tahun 2013

[2] Brooks, G.,\& Wilson, J. (2014). Using oral presentations to improve students' English language skills. Kwansei Gakuin University Humanities Review.19 (1), 199-212

[3] Girard, T.,Pinar, A. M., \& Trapp, P. (2011). An exploratory study of class presentations and peer evaluations: Do students perceive the benefits? Academy of Educational Leadership Journal, 15(1), 77-93.

[4] Marzuki, AG. (2017): Developing Student Speaking Skills Through Oral Report in EFL Class in Indonesia: AL-TA'LIM JOURNAL, 24 (3), 2017

[5] Montoya, Oscar H. 2011. Information Gap Activities: A CommunicativeExperience in the Classroom. II NATIONAL BILINGUALISMCONFERENCE ARMENIA, May 12th/13th, 2011

[6] Rahmawati, (2017): Improving English Speaking Ability Using The Team-Games Tournament Technique, Shiah Kuala University, Banda Aceh

[7] Sagor,R. (2000). Guiding School Improvement with Action Reasearch. USA: Association for Supervision and Curriculum Development Retrieved from http://www.ascd.org/publications/books/100047/c hapters/What-Is-Action Research\%C2\%A2.aspx

[8] Sub Directorat KPS (Kurikulum dan Program Studi). (2008). Buku Panduan Pengembangan Kurikulum Pendidikan Tinggi. (Sebuah Alternative Penyusunan Kurikulum). Jakarta:
Direktorat Akademik, Direktorat Jenderal Pendidikan Tinggi.

[9] Tampubolon, S. (2014). Penelitian Tindakan Kelas: Sebagai Pengembangan Profesi Pendidikan dan Keilmuan.Jakarta: Erlangga. 